Kafkas Üniversitesi Sosyal Bilimler Enstitüsü Dergisi

Kafkas University Journal of the Institute of Social Sciences

Sonbahar Autumn 2020, Sayı Number 26, 805-822

DOI:10.9775/kausbed.2020.041

Gönderim Tarihi: 15.07.2020

Kabul Tarihi: 01.12.2020

TÜRKIYYE'DE 1945-1950 DÖNEMINNDE DIŞ POLITIKKA

\title{
Turkish Foreign Policy During 1945-1950
}

Gülay SARIÇOBAN

Doç. Dr., Hacettepe Üniversitesi

Atatürk İlkeleri ve İnkılap Tarihi Enstitüsü

Atatürk İlkeleri ve İnk1lap Tarihi

gulaysaricoban@gmail.com

ORCID ID: 0000-0002-9309-8363

Çalışmanın Türü: Araştırma

$\ddot{\text { Oz }}$

Bu çalışmada 1945-1950 döneminde, Sovyet tehditleri ile karşı karşıya kalan Türkiye'nin batıl devletlerden destek almaya çalışması, ABD ile yakınlaşması ve ABD'nin Türkiye'ye Truman Doktrini ve Marshall Planı çerçevesinde ekonomik ve askeri destek vermesi süreci incelenmiştir. Çalışmada Başbakanlık yayınları olan Ayın Tarihi ve Düstur, Cumhuriyet Arşivi, konuyla ilgili yayınlanmıs kitap ve bilimsel dergilerde yayınlanmış makalelerden yararlanılmıştır. İkinci Dünya Savaşı'na katılmayan ve tarafsız kalan Türkiye savaş sonrasında uluslararası ilișkilerde yalnız bırakıldı. Batılı devletlerden destek almak istemesinin nedeni ise Sovyetler Birliği'nin doğuda toprak talebinde bulunmasi ve Boğazlardan üs istemesi olmuştur. Dolaylsıyla, söz konusu dönemde daha çok ABD'den destek alan Türkiye yüzünü Batı'ya çevirmiştir.

Anahtar Kelimeler: Türk Dış Politikası, Sovyetler Birliği, ABD, Truman Doktrini, Marshall Plant.

Abstract

In this study it has been scrutinized that Turkey that encountered the Russian threats tried to get support from the western nations, it got closer to USA and the process that the USA gave her economic and military support according to Truman Doctrine and Marshall Plan. In this study Ayln Tarihi and Düstur published by the Prime Ministry, the Republican Archive, the books published on the same topics, and the articles published in the scientific journals were consulted. Turkey that didn't take part in World War II and stayed impartial was left alone after the war. The reason why it wanted to get support from the Western Countries is that the Soviet Union demanded land in the east and required bases along the straits. As a result, in the mentioned era Turkey that got support much from the USA turned its face to the West.

Keywords: Turkish Foreign Policy, Soviet Union, USA., Truman Doctrine, Marshall Plan.

\section{GİRIŞ}

İkinci Dünya Savaşını izleyen ilk yılda Türkiye'nin dış politikasının en önemli sorunu, savaş içinde düştüğü yalnızlıktı. Savaş içinde, batılı müttefiklerin Amerika Birleşik Devletleri'nin etrafında ve "Birleşmiş Milletler" adı altında yapmış oldukları sıkı işbirliğinin savaştan sonra da devam ettirilebilmesi için birçok çalışmalar yapılmıştı. Bu çalışmalar sonunda alınan işbirliği kararlarına Sovyetler Birliği'nin da katılmış olması, 
bu devletlerin muhtemel tehditleri ve Türkiye aleyhine genişleme teşebbüsleri karşısında Türkiye'nin diğer büyük devletlerin desteğini aramasını çok güçleştirmişti. Savaşın son anında Mihver devletlerine savaş ilan etmesi ile asli üyeleri arasına girmeyi bir hak olarak kazandığı Birleşmiş Milletler Teşkilatının kurulması amacıyla 25 Nisan 1945'te toplanan San Fransisko Konferansında, Türkiye, bu yalnızlı̆̆ını belirli bir biçimde hissetmiştir. Kurulacak teşkilat esas olarak savaşı kazanan devletlerin bir teşkilatı olduğu ve savaş sonu dünyasını bu devletlerin istek ve çıkarlarına göre yürüteceği için, savaş sırasında çatışmaya katılmaktan dikkatle kaçınan Türkiye, şimdi bu çekimserliğin olumsuz etkilerini görmekten ciddi olarak endişe duymuştur (Gönlübol, 1974, s.205).

Türkiye'nin Sovyetler Birliği karşısındaki endişeleri savaş yılları boyunca devam etmiştir. Türk-Sovyet ilişkileri savaşın seyrine göre değişiklikler göstermiştir. Savaşın Müttefikler tarafından kazanıldığının kesinleşmesinden sonra Sovyetler'in Türkiye'ye bakış açısı değişmiş ve gerçek niteliğine kavuşmuştur (Sarınay, 1988, s.42). Türkiye'nin savaşın sonunda içine düştüğü yalnızlık Sovyetleri ümitlendirmiş ve Türkiye üzerindeki isteklerinin gerçekleşmesi konusunda elverişli bir ortam yaratmıştır.

\section{SOVYETLER BİRLİĞI'NINN TÜRKIYYE'DEN İSTEKLERİ}

25 Aralık 1925 Türk-Sovyet Tarafsızlık ve Saldırmazlık Antlaşmasının 19 Mart 1945'te feshinden yaklaşık 2.5 ay sonra Sovyetler Birliği yeni bir anlaşma için Türkiye'nin ya da herhangi bir egemen devletin kabul edemeyeceği türden talepler ileri sürdüğü görülmektedir. Türkiye'nin Moskova Büyükelçisi Selim Sarper ile 7 Haziran 1945'te gerçekleşen görüşmede Sovyet Dışişleri Bakanı Molotov, şayet Sovyetler Birliği ile anlaşmak istiyorsa Türkiye'nin aşağıda sıralanan Sovyet isteklerini kabul etmesi gerektiğini bildirmiştir:

1- 16 Mart 1921 tarihli Moskova Antlaşması ile tespit edilen TürkSovyet sınırında Sovyet Cumhuriyetleri lehine bazı düzeltmeler yapılması.

2- Boğazların Türkiye ile Sovyetler Birliği tarafindan ortaklaşa savunulması ve bunu sağlamak için de Sovyetler Birliği'ne Boğazlarda deniz ve kara üsleri verilmesi.

3- Boğazlar rejimini tespit eden Montreux Sözleşmesinde de yapılması gerekli değişiklikler konusunda Türkiye il Sovyetler Birliği arasında antlaşmaya varılması ("TC. Başbakanlık Arşivleri, Cumhuriyet 
Arşivi, Başbakanlık Basın ve yayın Umum Müdürlüğü", 12.04.1946 tarih ve 101.625. 3 nolu belge).

18 Haziran'da gerçekleşen ikinci görüşmede ise, Dışişleri Bakanı bir Balkan sorunundan söz etmiş, buna bağlı olarak toplanacak olan Balkan ülkeleri konferansina Türkiye'nin de katılmasıyla bölgede etkin bir rol oynayabileceğinin üzerinde durmuştur ("Türkiye Dış Politikasında 50 y1l, 1973, İkinci Dünya Savaş1 Y1lları (1939-1946)" s.171-172). Bazı araştırmacılar bu teklifin Sovyetler Birliği'nin Türkiye'yi Balkan ülkeleri çerçevesinde ele aldığını ve Türkiye'de Sovyetlere yakın bir hükümetin kurulmasını arzuladığını düşünmüşlerdir (Alacakaptan, 1999, s.287).

Sovyetler Birliği'nin Montreux rejiminden duyduğu rahatsılılk biliniyordu. Hatta konuyu çeşitli vesilelerle dile getirmişler ve Boğazların savunulmasına ortak olmak istemişlerdi. Ancak, Türk-Sovyet sınırında toprak talepleri ve Türkiye'de görmek istedikleri rejim ile ilgili amaçlarını (toprak ve Balkan sorunu ile ilgili argümanlarını sadece Boğazlar sorununu çözümlemek amaciyla konuyu yaymak veya bir koz olarak öne sürdükleri düşünülse bile) ilk defa gündeme getiriyorlardı (Barutçu, 1977, s.313).

Dolayısıyla Türkiye'nin bahsi geçen Sovyet isteklerini kabul etmesi beklenemezdi. Büyükelçinin Sovyet Dışişleri bakanına yanıtı şu olmuştur:

"Sovyetlerin ülke isteklerinin, Boğazların savunulmasına katılma ve üs verilmesi isteklerinin kabulüne imkân yoktur. Montreux Sözleşmesinin değiştirilmesi, Türkiye ve Sovyetler Birliği gibi bu sözleşmeye taraf olan bütün devletleri ilgilendiren bir sorundur"' (Çelik, 1969, s.123)

Türk hükümetinin Sovyet isteklerini reddetmesi üzerine, Sovyetler Birliği 1945 yılının ortalarından başlayarak Türkiye üzerinde ağır bir siyasi baskı kampanyasına girişmiş, Sovyet radyo ve gazeteleri bazı Türk illerinin, bu arada Kars ve Ardahan'ın Sovyetler Birliği'ne bırakılması yolunda yayınlar yapmaya başlamışlardır.

O zamana kadar her şeye rağmen Sovyetlerle dost kalmak çabasını gösteren Türkiye bu istekler karşısında bağımsızlığını ve toprak bütünlüğü bakımından büyük bir endişe duymaya başlamıştır. Türkiye, silahlı bir Sovyet saldırısına uğradığı takdirde, tek başına da olsa, bu saldırıya karşı koymaya kararlı olduğunu çeşitli yollardan dünya kamuoyuna duyurmuştur. Öte yandan, iktisadi ve askeri gücünü göz önünde tutarak, Sovyetler birliği karşısında yalnız kalmak istemediği için, Türkiye 1939 yılından beri ittifak bağı ile bağlı olduğu İngiltere'nin ve İkinci Dünya Savaşı sonunda en kuvvetli devlet olarak beliren ABD'nin desteğini kazanmaya çalışmıştır 
(Gönlübol, 1974, 207-208).

\section{TÜRKIYYE \\ 3. POTSDAM KONFERANSI, BOĞAZLAR SORUNU VE}

Amerika Birleşik Devletleri, İngiltere ve Sovyetler Birliği'nin savaş sonu işbirliğini gerçekleştirmek amaciyla düzenledikleri Potsdam Konferans1, 17 Temmuz-2 Ağustos 1945 tarihleri arasında Berlin'de toplanmıştır. Konferans başladığı sırada Amerikanın başkanı artık Roosvelt değildi. Onun ölümü üzerine 1945 Nisanı'nda iş başına Truman geçmiştir. Konferans devam ederken İngiliz idareciler de değişmiş, 26 Nisan 1945'te yapılan seçimler sonunda Churchill ve Eden yerlerini Attlee ve Bevin'e bırakmışlardır. Diğer yandan, Yalta ve Potsdam Konferansları arasında uluslararası ilişkilerde önemli gelişmeler meydana gelmiş ve üç büyük devlet arasında savaş içinde başlayan işbirliğinin savaş sonunda devam edip edemeyeceği konusunda tereddütler ortaya çıkmıştı (Ülman, 1961, s.60).

Konferansta Sovyetler Birliği Komünist Partisi Genel sekreteri ve Başbakan Stalin, Türkiye'ye bildirmiş oldukları Boğazlarla ilgili taleplerini tekrar ortaya atarak boğazlarda Sovyet kara ve deniz üsleri inşasını istediklerini bir kez daha tekrarlamıştır. Ona göre; Boğazlar sorunu Türkiye ile Sovyetler Birliği arasında çözümlenmesi gereken bir sorundur. StalinAmerikan Cumhurbaşkanı Truman'ın Boğazların Türkiye ile Sovyetleri ilgilendiren bir sorun olduğu, bu nedenle boğazlar statüsünün bu iki devletin tespit ve tayin edecekleri yolundaki Sovyet tezine karşı Boğazlara uluslararası bir su yolu statüsünün verilmesini ve ilgili devletlerin teminatı altına konulması teklifini reddetmiştir (Sönmezoğlu, 2006, s.34). İngiltere Başbakanının Boğazların iki devlet arasında bir sorun olmadığını ve Boğazlarda Sovyetlere üs verilmesine karşı olduğu görüşü de reddedilmiştir. Nihayet gerek ABD gerekse İngiltere Boğazlarda Sovyet gemilerinin geçişini üç büyük devletle ilgili devletlerin teminatı altına koyma teklifleri de reddedilince sorun askıda kalmıştır ("Foreign Relations of The United States Diplomatic Papers", 1960, s.302).

Böylece Postdam Konferansı'nda Boğazlar rejiminin değiştirilmesi konusunda bir anlaşmaya varılamamış ve meselenin Londra'da yapılacak olan Dışişleri Bakanları toplantısında ele alınmasına; alınan bir kararla da her üç devletin Boğazlar rejimi konusundaki görüşlerini ayrı ayrı Türkiye'ye bildirmelerine karar verilmiştir (Bilge, 1992, s.288).

Postdam Konferansı'ndan sonra ABD'nin Boğazlar hakkındaki politikasında bir değişikliğin olduğu görülmektedir. ABD yönetimi, Türk boğazlarının bütün milletlerarası su yolları gibi genel bir milletlerarası 
statüye konulması ve bütün devletlerin boğazlardan geçiş serbestliğine sahip olmaları şeklindeki görüşünü bir süre sonra değiştirmiş ve diğer milletlerarası su yolları ile Türk boğazlarının durumunun birbirinden ayrılması görüşü savunulmaya başlanmıştır (Ülman, 1961, s.62-63). Gerçekten de 1945 sonları ve 1946 y1lı boyunca gelişen olaylar, ABD yönetiminin Türk boğazlarına milletlerarası bir statü verilmesi fikrinden, Boğazlardan Sovyetlerin istediği gibi iki devletin, yani Sovyetler Birliği ile Türkiye'nin değil, yalnızca Türkiye'nin egemenliği altında bırakılmasını savunmaya başladığını göstermiştir.

ABD yönetiminin Türk boğazları konusundaki değişen tutumunu gösteren ilk belge, Postdam Konferansında alınan karara uygun olarak 2 Kasım 1945'te Türkiye'ye verilen Amerikan notasıdır (Ayın Tarihi, No:144 Kasım 1945, s.71). Notada Amerikan hükümeti boğazlar rejimini günün koşullarına uyumlu hale getirmek için bir konferansın toplanmasını öneriyor ve davet edilmesi halinde söz konusu konferansa katılma isteğini açıklıyordu. Amerikan notasına göre yeni Boğazlar rejimi aşağıdaki gibi olmaliydı:

1- Boğazlar savaş ve barış zamanında bütün ulusların ticaret gemilerine açık olmalıdır.

2- Boğazlar her zaman Karadeniz'de sahil sahibi devletlerin savaş gemilerinin transit geçişine açık olmalıdır.

3- Barış zamanında birlikte anlaşma yoluyla saptanacak sınırlı bir tonaj dışındaki gemilerle Karadeniz'de sahili olmayan devletlerin savaş gemilerine, sahil sahibi devletlerin onayları veya BM'nin otoritesi altında hareket etmeleri halleri dışında boğazlar kapalı tutulmalıdır.

4- Boğazlarla ilgili olarak gündemleştirilecek yeni sözleşme günün koşullarını yansıtır içerikte olmalıdır. Örneğin, Milletler Cemiyeti sistemi yerine Birleşmiş Milletler sisteminin geçirilmesi veya taraf olarak Japonya antlaşmadan çıkartılmalıdır (Gürün, 1991, s.300-301).

Amerikan notasının ikinci ve üçüncü maddelerinde ortaya konan görüşler Türk hükümeti tarafından sakıncalı bulunmuş, Amerika'nın toplanması öngörülen konferansa katılma arzusu ise olumlu karşılanmıştır.

Amerikan notasıyla neredeyse aynı içerikli bir nota da $21 \mathrm{Kas} ı m$ 1945'te İngiltere'nin Ankara Büyükelçisi Peterson tarafından Dişişleri Bakanı Hasan Saka'ya verilmiştir. Notada Amerikan notasında öngörülen hususlarda antlaşma sağlanabileceği belirtilmiş ve bu doğrultuda konu ile ilgili olarak Türk ve Sovyet hükümetlerinin yapacakları uluslararası bir 
konferans önerisine İngiltere Hükümeti'nin de olumlu yaklaşacağ1 görüşü dile getirilmiştir (Ayın Tarihi, Aralık 1945, s.15).

\section{TÜRKIYYE ABD YAKINLAŞMASI}

İkinci Dünya Savaşı'nın müttefiklerin zaferi ile sonuçlanması, Türk devlet adamlarının gözünde demokrasi ve demokratik rejimin üstünlügünü açıç̧a ortaya koymuştu. Bu nedenle daha önce de dile getirdiğimiz gibi savaşın sonlarına doğru milletlerarası dengede batılı devletlerin yanında yer alabilmek için, savaş içindeki tarafsızlık politikasından uzaklaşmış ve batılı devletlerle işbirliği yapmıştır.

Türk devlet adamlarının batılı devletlerle işbirliğine gittiği savaşın son günlerinde Türkiye üzerindeki Sovyet baskısı ve tehdidi, batı ile ilişkilerin geliştirilmesi için Türk devlet adamlarını harekete geçirmiştir. Sovyet tehdidi karşısında batı dünyasının desteği aranmış ve sonuçta $A B D$ ve İngiltere'nin diplomatik desteği sağlanmıştır.

ABD'nin Türkiye hakkındaki görüşlerinin Postdam Konferansı'ndan sonra değişmeye ve 1945 y1lı sonbaharından itibaren Türkiye'nin toprak bütünlüğü ile yakından ilgilenmeye başladığını görüyoruz. ABD'nin Türkiye'ye karşı politikasının değişmesinde iki önemli olay etkili olmuştur. Bunlardan ilki Sovyetlerin Türkiye'den talep ettiği toprak meselesidir. Nitekim ABD Başkanı Truman bir yazısında 'Sovyetler Birliği'nin Türkiye'yi istila ederek Boğazlar Bölgesi'ni ele geçirmek istediğine artık hiç şüphem kalmadı. Eğer bu gidişe demirden bir yumruk uzatıp dur! demezsek yeni bir savaş çıkacak" (Ülman, 1961, s.69). Diyerek Sovyetlerin savaş sonu istilacı emeller taşıdığını belirtmekte ve Sovyet tehdidine karşı Türkiye'yi himaye etmenin önemini belirtmektedir.

ABD'nin Türkiye'ye karşı takip ettiği politikanın değişmesinde diğer bir olay da, 1945-1946 kış1 boyunca dünya siyaset sahnesinin gündemini işgal eden "İran Meselesi"dir. ABD yönetimi İran meselesini Sovyetler'in bölgedeki durumu, İran petrolleri ve Türkiye'nin güvenliği bakımından önemli görmekte idi (Ülman, 1961, s.71-72).

Türk-ABD ilişkilerinin gelişmesinde ABD Hükümeti'nin 1946 Nisan'nda Türkiye'nin Washington Büyükelçisi Münir Ertegün'ün cenazesini Missouri zırhlısıyla Türkiye'ye göndermesi önemli bir etki yapmıştır. Amerikan donanmasının en büyük zırhlılarından biri olan Missouri'nin Türkiye'ye gelmesi ve beraberinde eski Türkiye Büyükelçisinin cenazesini de getirmesi Türk-Amerikan ilişkilerinde sembolik bir anlam kazandırmıştır. Nisan başlarında Türkiye'ye gelen 
Missouri gemisi büyük ve görülmemiş bir coşkuyla karşıllanmıştı. Nitekim ABD’nin Ankara Büyükelçisi Washington'a gönderdiği bir raporda "Bu, Birleşik devletler donanması subaylarına ve erlerine karşı gönderilmiş dostluk ifadesinin her halde en dikkate şayan olanıdır" diyerek, Türk hükümeti ve kamuoyunun gösterdiği olumlu yaklaşımı işaret etmiştir. Gerçekten de Türk Kamuoyu, gerek ABD’nin Türkiye üzerindeki Sovyet baskı ve tehditlerine karşı takındığ 1 tutum ve politikasını değiştirmesini ve gerekse Missouri zırhlısının Türkiye'ye gelmesini, ABD'nin Sovyetler Birliğine karşı Türkiye'ye teminat vermesi olarak değerlendirilmiş ve sevinçle karşılanmıştır (Timur, 1991, s.44).

Postdam Konferansı'ndan sonra ABD ve İngiltere'nin desteğinin sağlanması, Türkiye üzerindeki Sovyet tehdit ve baskılarının sona ermesini sağlayamamıştır. Nitekim Sovyetler 8 Ağustos 1946'da Türk Boğazları ile ilgili görüşlerini ihtiva eden bir notayı Türkiye'ye vermişlerdir. Sovyetlerin bu notasında; Boğazların Karadeniz devletlerinin savaş gemilerine açı tutulması, Boğazların Karadeniz'de sahili olmayan devletlerin savaş gemilerine kapalı tutulması, Boğazlardan geçiş rejiminin Türkiye ile Karadeniz devletlerine ait olması gibi esaslar belirlenmiştir (Armaoğlu, 1931, s.148-151).

Türk Hükümeti, Sovyetlerin bu notasına cevap vermeden önce konuyu $\mathrm{ABD}$ yönetimine götürmüş ve $\mathrm{ABD}$ 'nin bu konudaki görüşlerini öğrenmek istemiştir. ABD yönetimi Sovyet notasını görüşmüş ve bu notayla Sovyetlerin, Türkiye'yi hâkimiyeti altına almayı planladığını, bu ülkeden sonra sıranın Yunanistan'a geleceğini, bu iki ülkenin kaybedilmesinin Ortadoğu ve Akdeniz'de büyük bir felakete sebep olacağını düşünmüş Sovyetlerin Türkiye ve Boğazlar üzerindeki istekleri dikkate alınarak ciddi bir politikanın takip edilmesi kararlaştırılmıştır (Gürün, 1991, s.306; Ülman, 1961, s.79-81). ABD yönetiminin politikasında meydana gelen bu değişiklik, ABD'nin Türkiye'ye karşı takındığı ve takip ettiği politika konusunda bir aşama olmuştur.

Nitekim ABD yönetimi 16 Ağustos 1946'da aralarında Roosevelt uçak gemisinin de bulunduğu bir deniz gücünü Akdeniz'e göndereceğini açıklamıştır. Ayrıca ABD Boğazlarla ilgili görüşlerini belirten bir notayı da Sovyetler Birliği'ne vermiştir. $\mathrm{Bu}$ notada ABD Yönetimi; Boğazlar meselesinin ABD ve bütün ülkeleri ilgilendirdiğini, Türkiye'nin Boğazlardan sorumlu tek devlet olarak kalmaya devam etmesini ve şayet Boğazlara yönelik bir saldırı olursa Birleşmiş Milletler Güvenlik Konseyi'nin duruma el koymasını bildirmiştir (Ülman, 1961, s.80-81). İngiltere ise ABD'nin belirttiği bu esasları ihtiva eden bir notayı Sovyetlere 
vererek Türkiye'yi bu konuda yalnız bırakmayacağını belirtmiştir (Erkin, 1986, s.296).

Türk Hükümeti ise, Sovyet Notasını TBMM'ne götürmüş ve bu konu 14 Ağustos 1946'da TBMM'de tartışılmıştır. TBMM'de yapılan görüşmelerde Recep Peker Hükümeti, Türkiye'nin Toprak bütünlüğünün ve bağımsızlığının her şeyden üstün tutulacağını, İngiltere ile olan ittifakın geçmişte olduğu gibi gelecekte de dış politikamızın temeli olarak kalacağını ve $A B D$ ile olan münasebetlerin daha da geliştirileceğini açıklamıştır. İngiltere ve ABD'nin desteğini kazanan Türkiye, Sovyet notasına cevap vermiştir. $\mathrm{Bu}$ notada, Sovyet notasındaki bazı isteklerin göz önünde tutulacağı belirtilmekte ve Boğazların birlikte savunulması konusundaki Sovyet teklifi tamamen reddedilmektedir ("Türkiye Dış Politikasında 50 yıl, İkinci Dünya Savaşı Yı1ları (1939-1946)”, 1973, s.295-297).

Bundan sonra, 24 Eylül 1946'te Sovyetlerin aynı doğrultuda bir notayı Türkiye'ye ikinci defa verdiğini görüyoruz (Ayın Tarihi, No:154 Eylül 1946, s. 46-51). Türkiye, Sovyet notasından ABD ve İngiltere'yi haberdar etmiş ve ilk notada olduğu gibi $A B D$ ve İngiltere'nin desteğini sağlamaya çalışmıştır. $\mathrm{Bu}$ çabaların neticesi olarak $\mathrm{ABD}$ ve İngiltere, Sovyetlere ayrı ayrı verdikleri notalarla Türkiye'yi desteklediklerini bir kez daha göstermişlerdir.

Kısaca anlatmaya çalıştığımız gibi, 1945 yılında Türkiye üzerinde yoğunlaşan Sovyet baskı ve tehdidiyle Türk devlet adamlarında savaş sonrası düzenle ilgili olarak ciddi tedirginlikler yaratmıştır. Türkiye bağımsızlığını ve toprak bütünlüğünü korumanın ve üzerindeki ağır Sovyet baskısını etkisiz kılmanın yegâne yolunun batılı devletlerin desteğini sağlamak olduğunu görmüştür. $\mathrm{Bu}$ nedenle, savaş sonrası Türk dış politikasının temel hedefi, İngiltere ve ABD'nin Türkiye ve Türk Boğazlarıyla ilgilenmesini sağlamaya çalışmak olmuştur. Aynı zamanda Türkiye, Sovyet tehdidine karşı ABD’nin diplomatik desteğini sağlamaya çalışırken iyice kötüleşmiş olan iktisadi durumunu güçlendirmek amacıyla ABD’nin ekonomik desteğini sağlamaya da büyük önem vermiştir. 1946 yılı sonlarında başlayan bu ekonomik yakınlaşma 1947 yılında Truman Doktrini çerçevesinde gelişecek ve Marshall yardımıyla doruk noktasına ulaşacaktır.

\subsection{Truman Doktrini}

Daha İkinci Dünya Savaşı sırasında Türkiye hem İngiltere'den hem de ABD'den askeri yardım almıştı. Gerçekten ABD bu savaş boyunca Ödünç Verme ve Kiralama Kanunu gereğince ve dört yıl süreyle yaptığ 1 yardım, iki devlet arasında bir anlaşma konusu olmamıştı. Savaşın son 
günlerinde ise $\mathrm{ABD}$ bu yardımı bir anlaşmaya bağlamak istemiş ve iki hükümet arasında yapılan görüşmeler sonunda, 23 Şubat 1945'te Ankara'da bir anlaşma imzalanmıştır. Bu anlaşma gereğince, Türkiye savaş devam ettiği müddetçe ABD'nden savunma madde ve hizmetleri almağa devam edecek, buna karşılık savaş sona erdiği zaman, bu anlaşma gereğince kendisine devredilmiş olan savunma maddelerinden imha, kayıp veya istihlak edilmemiş olanlardan Amerikan hükümetinin lüzum göstereceklerini geri verecektir. Ancak, savaşın sona ermesiyle birlikte ABD bu yardımı kesince, Türkiye yalnız İngiltere'nin yardımıyla yetinmek zorunda kalmıştır (Gönlübol, 1974, s.225-226).

Ancak, İngiliz Hükümeti 21 Şubat 1947 tarihinde bir nota vererek, "Yunanistan ve Türkiye'ye savaşın sona ermesinden beri yapılan ekonomik yardımın 1947 Martı'ndan sonra kesileceğini” bildirdi (Ülman, 1961, s.94; (Sönmezoğlu, 2006, s. 37 ). İngiltere'nin ABD’ye vermiş olduğu bu nota, bundan böyle onun dünya, özellikle Ortadoğu'daki yerini bu ülkeye terk etmek zorunda kaldığını da ortaya sermekteydi.

İngiltere'nin ABD'ye verdiği bu nota üzerine, Amerikan yönetimi Türkiye ve Yunanistan'a yardım kararı almıştır. Başkan Truman bu amaçla Senato ve temsilciler Meclisi’nin 12 Mart 1947 tarihinde yaptığ 1 ortak oturumda, sonradan Truman Doktrini olarak anılacak olan bir mesaj okumuştur. Amerikan dış politikasında yeni bir çağın başlangıcı sayılan bu mesajında Başkan Truman, Kongre üyelerine Türkiye ve Yunanistan hakkında geniş bilgi vermiştir. Başkan, ABD’nin Birleşmiş Milletler ilkelerine bağlılık ve saygınlığını belirttikten sonra, "Amerikan dış politikasının kendilerini boyunduruk altına almak için silahlı azınlıklar tarafindan harcanan çabalar ve dış baskılara karşı koymaya çalışan özgür ulusları desteklemek amacına yönelmesi gerektiği kanısındayım" diyerek (Oran, 2002, s.528)devamla, Kongreden hükümete, Türkiye ve Yunanistan'a 400 milyon dolarlık yardım yapmak ve bu devletlerin isteği üzerine sivil ve askeri personel göndermek ve Türk ve Yunan personelinin ABD'lerinde yetiştirilmesini sağlamak yetkisinin verilmesini istemiştir (Satterthwaite, 1972, s.78) .

Mesajın dikkate değer bir yönü ise, Türkiye için öngörülen 100 milyon dolarlık yardımın Başkan Truman'ın "bağımsız ve ekonomik olarak güçlü” bir ülke olarak tanımlayarak, ekonomik yardım yapılmasını gerekli görmediği Türkiye'ye yalnızca askeri yardım olarak verilmesinin istenmesidir. Oysa Yunanistan için öngörülen 300 milyon dolarlık yardımın ekonomik ve askeri olarak iki ayrı amacının olduğu görülmektedir. 
Ayrıca Amerika Cumhurbaşkanı, Kongrenin 12 Mart 1947 tarihli birleşik oturumunda okuduğu mesajında, Türkiye ve Yunanistan'a yapılacak Amerikan yardımının temel felsefesine de işaret edilmiştir. Bu bağlamda yardımın Amerikan çıkarları için ne derece önemli olduğunun altını da açıkça çizmiştir.

Truman'a göre: “Türkiye ve Yunanistan'a gerekli yardım yapılmazsa bu ülkelerin de Bulgaristan, Romanya ve Polonya gibi totaliter bir baskı altına düşmeleri önlenemeyecekti. Ortadoğu'nun istikrarı ve bölgedeki Amerikan çıkarları için, Türkiye ve Yunanistan'a yardım yapılmas1 zorunluydu" (Oran, 2002, 528-529).

Sonuçta Truman'ın isteklerine uygun olarak hazırlanan "Yunanistan ve Türkiye'ye yardım kanunu" Kongrece kabul edildikten sonra 22 Mayıs 1947'de kendisi tarafından imzalanarak yürürlüğe girmiş̧ir (Düstur, III. Tertip, Cilt 28, s. 1485-1488).

Ayrıca, söz konusu kanunun ilgili ülkelerde amacina uygun kullanılıp kullanılmayacağının denetlenmesi gerektiğine de işaret edilmiştir. Kanunun Kongrede kabulü öncesinde yapılan ve "Vandenberg Değişikliğĭ" olarak bilinen değişikliğe göre, BM Güvenlik Konseyi ya da Genel Kurul, Yunanistan ve Türkiye'ye yapılan yardımın kesilmesini isterse, Yunanistan ve Türk hükümetleri yardımı artık istemediklerini bildirirlerse, Amerikan Başkanı yardımının amacına ulaştığına ya da hiçbir zaman ulaşmayacağına hükmederse yardımlar sona erdirilecekti.

Nihayet, söz konusu kanun gereğince yapılacak yardım, Amerikan başkanının bilgi ve onayı olmadan Türkiye ve Yunanistan tarafindan amaçları dışında kullanılmayacaktı. Türk ve Yunan hükümetleri kendilerine yapılan yardımın yerinde ve amacına uygun olarak kullanılıp kullanılmadığını denetlemek için ülkelerine gönderilecek personele gerekli bilgiyi vermekten kaçınmayacakları gibi, Amerikan basın yayın kuruluşları temsilcilerinin yardımın kullanılması konusunda ülkelerinde serbestçe inceleme yapıp bilgi toplamalarına da engel olmayacaklardı (Çelik, 1969, s.69).

Truman Doktrininin yürürlüğe girmesi bir yandan Sovyetler Birliği'nin şiddetli tepkilerine yol açarken (Sovyetler Birliği, bu Amerikan yardımının dünya barışı için ciddi bir tehdit olduğunu ileri sürerek meseleyi Birleşmiş Milletler Genel Konseyine getirmiş, fakat hiçbir sonuç alamamışırı), diğer yandan da Türk Hükümeti tarafından büyük bir memnunlukla karşılanmıştır. İsmet İnönü bu vesile ile yayınladığı bir mesajda, "Büyük Amerika Cumhuriyetinin memleketimiz ve milletimiz 
hakkında beslemekte olduğu yakın dostluk duygularının yeni bir örneğini teşkil eden bu sevinçli olayı" her Türkün candan alkışladığını söylemekte ve "İkinci Dünya Savaşı sırasında ve savaşın fiilen sona ermesinden sonra milletimizin ispat ettiği yüksek meziyet ve ideallerin dünya efkârı umumiyesi tarafından takdir edildiğini gösteren bu yardım, Türkiye'ye zaruri ve normal savaş malzemesinin bir kısmını temin etmek suretiyle, savaş sonunda düşmüş bulunduğumuz iktisadi güçlüklerin kısmen giderilmesinde de ferahlatıcı bir etken olacaktır" demektedir. Gene aynı mesajda belirttiğine göre, ABD'nin Türkiye'ye ve Yunanistan'a yardım etmek kararını vermesi, "ABD'nin, cihan başarının devam ve teyidi uğrunda kendisine düşen büyük rolü tamamıyla benimsediğini gösteren önemli bir işarettir (Gönlübol, 1974, s.230).

\subsection{Temmuz 1947 Türk-Amerikan Askeri Yardım} Antlaşması

Yunanistan ve Türkiye'ye yardım kanununun Başkan Truman tarafindan onaylanmasından bir gün sonra, 23 Mayıs 1947'de Amerikan Dışişleri, Harbiye ve Donanma Bakanlıkları temsilcilerinden kurulu olan ve Genaral Lunsford Oliver başkanlığındaki bir Amerikan inceleme kurulu Ankara'ya gelerek Türkiye'ye yapılacak yardım konusunda çalışmalara başlamıştır. $\mathrm{Bu}$ heyetle Türk sorumlular arasında yapılan görüşmeler yaklaşık 6 hafta sürmüş ve sonuçta, Amerikan Hükümetine verilmek üzere Türk ordusunun hangi alanlarda ne kadar yardım görmesi gerektiği konusunda bir rapor hazırlanmıştır.

Oliver heyeti bu raporunda, Türkiye'nin bir yandan savunma gücünü çoğaltmak diğer yanda da ekonomik gücünü kuvvetlendirmek için silahaltındaki asker sayısının azaltılmasını buna karşılık Türk Ordusundaki silahların modernleştirilmesini tavsiye etmiştir. Heyete göre; Yunanistan ve Türkiye'ye yardım kanunu gereğince Türkiye'ye yapılacak olan 100 milyon dolarlık yardım, bu modernleştirme işinde kullanılmalıdır. Eğer gelecek yıllarda da Türkiye'ye aynı oranda yardım yapılacak olursa, Türkiye 3 yıl içerisinde savunma konusunda kendi kendine yeter duruma gelecektir (Gönlübol, 1974, s.231).

Oliver kurulu ile Ankara'da görüşmeler yürütülürken, Türkiye ile ABD arasında Truman Doktrininin uygulanmasını sağlayacak olan antlaşmanın da hazırlıkları yapılıyordu (Çelik, 1969, s.131). Sonuçta antlaşma Amerika'nın Ankara Büyükelçisi Wilson ile Dışişleri Bakanı Hasan Saka arasında 12 Temmuz 1947 tarihinde imzalanmıştır (Tunçkanat, 1969, s.194). 
Amerika'nın İkinci Dünya savaşı sonrası ilk askeri yardım antlaşması sayılan 12 Temmuz 1947 antlaşmasının giriş bölümünde antlaşmanın neden imzalandığı şu sözlerle açıklanmıştı:

“Türkiye Hükümeti; Türkiye'nin hürriyetini ve bağımsızlığını korumak için ihtiyacı olan güvenlik kuvvetlerinin takviyesini emin ve aynı zamanda ekonomik istikrarını muhafazaya devam maksadıyla, Birleşik Devlet Hükümeti'nin yardımını istediğinden ve Birleşik Devletler Kongresi, 22 Mayıs 1947'de tasdik edilen kanun ile Birleşik Devletler Başkanına, Türkiye'ye, her iki memleketin egemen ve bağımsızlığına ve güvenliğine uygun şartlar dairesinde, böyle bir yardımda bulunmak yetkisini verdiğinden ve Türkiye Hükümeti ile Birleşik Devletler Hükümeti böyle bir yardım yapılmasının esas gayelerine ulaşmayı sağlayacağı gibi münasebetlerde hayırlı bir devre açarak Türk ve Amerikan milletleri arasındaki dostluk bağlarının daha da kuvvetlenmesi temennisiyle böyle bir anlaşmaya gerek duyulmuş̧tur" (Ertuğ, 1947, s.145).

Antlaşma Türk Hükümeti ve Kamuoyu tarafından genel olarak olumlu karşılanmasına rağmen bazı noktalarda çekincelerin ortaya görülmektedir. Bu noktalardan en önemlisi, Amerika'nın yapılacak yardımın amacına uygun olarak kullanılıp kullanılmadığını denetlemek isteği ile bu çeşit denetimin Türkiye'nin içişlerine müdahaleye kadar götürülmemesini sağlamak çabasının uzlaştırılması olmuştur (Çelik, 1969, s.132). Çünkü Türkiye açısından bağımsızlığına aykırı düşecek, içişlerine müdahaleye yol açacak, kapitülasyonların yeniden canlandırılması sonucunu doğurabilecek yükümlülükler altına girilmesi tehlikesi ortaya çıkmıştır (Çelik, 1969, s.133).

Ancak Türkiye'nin bu tür endişelerini gidermek için çeşitli formüller kullanıldığ1 görülmektedir. Örneğin Antlaşmanın ikinci maddesinde Amerikan yardımının bağlı olacağı kayıt ve şartlar birer birer sayılmamış, bunun yerine "misyon şefi bu Antlaşma gereğince peyderpey yapılacak muayyen yardımın kayıt ve şartlarını Türkiye Hükümeti temsilcileriyle danışarak tespit edecektir" denilmiştir (Çelik, 1969, s.133).

$\mathrm{Ne}$ var ki, Antlaşmanın ikinci maddesinin son paragrafındaki "Türkiye Hükümeti yapılan yardımı tahsisi edilmiş gayeler uğruna kullanacaktır" koşulunda, yardımdan verilecek bilgi, askeri malzeme, araç ve silahların veriliş amacına uygun olarak kullanılabileceği belirtilmiş ve bunun dışındaki her türlü kullanım da yasaklanmıştır.

Antlaşmanın 4. Maddesinin 2. Paragrafinda: Birleşik Devletler Hükümeti'nin muvafakati olmadan hiçbir madde veya bilginin mülkiyet ve zilliyetinin devredilemeyeceği ve verildikleri amaç dışında kullanılmayacağı 
bütün ayrıntılarıyla bir kez daha tekrarlanarak kesinlik kazandırılmıştır (Tunçkanat, 1969, 194-195).

Nitekim Antlaşmanın en çok eleştirilen maddesi de bu olmuştur. İleride doğurabileceği sonuçları düşünülmeden kabul edilen ikinci ve dördüncü maddeler 1964 yılında ortaya çıkan Kıbrıs Krizi ve Türkiye'nin adaya çıkarma yapmak istemesi üzerine buna ABD'nin karşı çıkmasının dayanağını teşkil etmiş ve iki ülke arasında bir bunalımın doğmasına yol açmıştır.

Doğan Avcıŏluna göre; Dönemin karar alıcıları ve destekçileri Cumhuriyetin özünü oluşturan Kemalist hareketin kurulu düzene karşı devrimci, yani solcu bir hareket olduğu gerçeğini göz ardı ederek, dönem içerisinde solculuğu etkisizleştirme yoluna gitmişlerdir (Avcıoğlu, 1971, s.374-375).

Oral Sander ise 12 Temmuz 1947 Antlaşmasını bir "ittifak" antlaşması değil, tek taraflı bir yardım uygulaması olarak değerlendirmektedir. ABD, Türkiye'nin SSCB'ye karşı savunulması için hiçbir yükümlülük altına girmemişti. Yalnızca silah, malzeme ve para yardımımda bulunuyordu (Sander, 1993, s.29).

Yine antlaşmanın imzalandığı tarihlerde gerek basımdan gerekse kamuoyundan gelen eleştirilere dönemin Dışişleri Bakanı Hasan Saka 1947 Temmuz'unda TBMM'de yaptığı konuşmada şunları söylemiştir: “...Mutmain olsunlar, Ne Türk Hükümeti’nin ne de Amerikan Hükümeti’nin tarihinde her hangi bir mukavele yardım yoluyla müstakil, bağımsız bir devletin bağımsızlığına aykırı bir teşebbüs gösterebilir”. Böylece, 1947 yılından başlayarak yalnız Türk dış politikasına değil iç politikasına da, Amerikan faktörü etkili bir güç olarak yerleşiyordu (Avcıoğlu, 1971, 374375).

\subsection{Marshall Planı}

II. Dünya Savaşı boyunca Avrupa ülkelerinin birer yıkıntı durumuna gelmesi, ekonomilerinin altüst olmasi; özellikle savaş öncesinde ABD için çok önemli bir pazar olan bu ülke insanlarının satın alma gücünü de ortadan kaldırdığından Amerika çok önemli bir pazarını yitirmiş bulunuyordu. Üstelik bu Avrupa ülkelerinin çoğunun denizaşırı toprakları, sömürgeleri vardı., onların bu ekonomik çöküntüsü de Batı dünyası için büyük sakıncalar yaratabilecekti. İște Avrupa'daki ve dünyadaki genel durum bu iken ABD Dışişleri Bakanı General Marshall, Harvard Üniversitesi'nde 5 Haziran 1947'de yaptığ 1 bir konuşmada, hükümetin Avrupa'nın kalkınması için 
öngörülen planı açıklamıştır. Bu plana "Marshall Planı" denildi (Yetkin, 2002, s.366).

Marshall, şöyle konuşmuştu:

“ABD’nin dünyada düzgün ekonomik dengenin yeniden kurulması için elinden gelen her yardımı yapması ki bu denge kurulmadan siyasal birlik ve sağlam bir barış gerçekleşemez sağduyulu bir davranış olur. Politikamız herhangi bir ülkeye ya da politikaya karşı değil, yalnızca açlık, yoksulluk ümitsizlik ve kargaşaya karşıdır. Amacımız dünyada ekonomik yaşamın canlandırılması, böylelikle özgür kurumların oluşmasına siyasal ve sosyal koşulların ortaya çıkmasına yol açmak olmalıdır. Bu gibi yardımların, çeşitli bunalımlar ortaya çıktıkça, parça parça yapılmasının doğru olmadığına inanıyorum. Hükümetimizin ilerde yapacağı yardım, geçiştirici olmaktan çok çözüm getirici nitelikte olmalıdır. Kalkınma çabasına yardımcı olmağa istekli devletler $\mathrm{ABD}$ hükümetinin tam bir işbirliğine güvenebilirler. Ülkelerinin kalkınmasını engelleyici davranışta bulunan hükümetler ise bizden yardım beklememelidir. Hele, insanların yoksulluğunu sürdürerek siyasal ya da başka türlü çıkar sağlamağa çalışan hükümetler, siyasal partiler ya da gruplar ABD'nin direnciyle karşılaşacaklardır (Soysal, 1989, s.286).

Marshall'ın bu konuşmasında Avrupalıların bu amaçla kendi aralarında örgütlenip bir program yapmaları gerektiğini, ABD'nin bu örgüt ve programa destek vermesinin daha doğru olacağını söylediğini görüyoruz.

$\mathrm{Bu}$ konuşmadan çıkan ilk sonuç, liberal kapitalist sistemle bütünleşecek olan ülkelere yardım yapılacak olmasıdır. İkincisi, bu ülkelerdeki açlık ve yoksulluk yüzünden komünizmin yayılması önlemek amaçlanmaktadır. Ama Marshall Planının asıl amacı, Amerikan mallarına pazar bulmaktı. Bu o denli açık bir gerçekti ki, örneğin 1950'de Ankara'da yayınlanan ve Marshall Planını tanıtmayı amaçlayan bir propaganda broşüründe bile hiçbir sakınca bile görülmeden deniliyordu ki:

“Amerika'nın Avrupa'daki menfaati iktisadi olduğu kadar siyasidir. Avrupa memleketleri en iyi ananevi müşterilerimiz olup dünya ticaretinin gelişmesinde mühim bir rol oynamaktadırlar. Şayet Avrupa'daki durum bozulmaya devam etseydi, bütün Amerikan ticareti bundan mutazarrır (zarar görürdü) olurdu. İhracatımız, milli ekonomimizin bel kemiğini teşkil etmektedir. Bu sebeptendi ki, Amerikan malları için daha büyük Pazar olabilecek kuvvetli ve sağlam bir Avrupa meydana getirmenin menfaatimiz icabı olduğu pek aşikârdır" (Yetkin, 2002, s.367).

27 Haziran 1947'de is Marshall Planı'nı görüşmek üzere İngiltere ve 
Fransa'nın öncülüğünde Paris'te bir araya gelen 16 Avrupa ülkesi (İngiltere, Fransa, Belçika, İtalya, Portekiz, İrlanda, Yunanistan, Türkiye, Hollanda, Lüksemburg, İsviçre, İzlanda, Avusturya, Norveç, Danimarka ve İsveç) gereksinimlerini gösteren ortak bir rapor hazırlamışlardır (Ayın Tarihi, Eylül 1947, s.122-127). Bu rapor üzerine ABD 2 Nisan 1948'de bir dış yardım yasası kabul ederek, bir y1ldan beri Türkiye ve Yunanistan'a "Truman Doktrini” gereği yapılan yardımı da bu yasa kapsamına da almıştı (Ülman, 1961, s.96).

Paris'te 12 Temmuz'da toplanan İktisadi İşbirliği Konferansına Türkiye'de katılmış olması nedeniyle, kendisine 615 milyon Dolar dış yardım yapılmasını istemiş ancak bu isteği Marshall Planı'nın ulusal kalkınma programlarının finansmanı için değil, savaştan yıkılmış Avrupa'nın kalkınması için hazırlandığı gerekçesiyle geri çevrilmiştir.

Amerika'nın bu tutumu Türkiye'de geniş tepkiler yaratmış ve bazı çevrelerde bugün Türkiye'yi ekonomik bakımdan yalnız bırakan ABD'nin yarın da politik bakımdan yalnız bırakabileceği endişesi uyandırmıştır. Bu tepkiye yönelik olarak Türk Hükümeti Amerikan Hükümetine başvurarak Türkiye'nin durumunun siyasi ve coğrafi bakımdan çok önemli olduğunu, bu siyasi ve coğrafi durumun ister istemez mali ve iktisadi güçlükler yarattığını, kuvvetli olmanın tek şartının ekonomik kalkınma, ekonomik kalkınma için de tek yolun da dış yardım olduğunu söyleyerek Washington'un Türkiye'ye iktisadi yardım konusundaki tutumunu yeniden gözden geçirmesini istemiştir. Bunun üzerine $\mathrm{ABD}$, Türkiye'nin içinde bulunduğu iç ve dış koşulları göz önünde tutarak "Marshall Planı" içine almaya karar vermiş ve 4 Temmuz 1948'de iki ülke arasında bir Ekonomik İşbirliği Antlaşması imzalanmaya karar verilmiştir (Düstur, III. Tertip, Cilt 29, s. 1278-1289; Gönlübol, 1974, s.236).

"Truman Doktrini" ve "Marshall Planı" düşünce ve amaç bakımından Sovyetler Birliği’nin yayılmacı politikasına yönelik olarak hazırlanmıştı. Truman Doktrini, Sovyet saldırganlığına karşı olan ve daha çok Sovyet yörüngesine girmemek için direnen ülkeleri korumak için bir set çekmek siyasası olduğu halde, Marshall Planı'nın amacı, Avrupa ülkelerinin ekonomik sorunlarını çözerek Avrupa'nın Sovyetlerin etkisi altına girmesini önlemeye yönelikti.

Marshall Planı'nın soğuk savaşı başlatan en önemli neden olması hiç kuşkusuz Sovyet tehdidi ile karşı karşıya kalmış bulunan Türkiye'nin az da olsa bir soluk almasını sağlamıştı ("Marshall Planı ve Siz", 1950, s.10). Ama Türkiye'nin Truman Doktrininden sonra Marshall planına katılması, Türk 
kamuoyunda ülkenin batı dünyasında yer edinmesi ve bu dünyanın yıldızı konumuna gelen $\mathrm{ABD}$ ile Sovyet tehdidine karşı, savunma işbirliğine yönelmesinde bir aşama olarak kabul edilecektir. Bundan böyle, batı dünyası yalnızca coğrafi ve teknik bir ilgi alanı değil, demokratikleşme alanında da bir çekim merkezi olarak görülüp değerlendirilmeye başlanacaktır (Esmer, 1948, s. 2)

Ayrıca Marshall Planı uyarınca Türkiye'ye verilen yardımların içeriği her ne kadar ekonomik olsa da, asıl amaç ülkenin askeri gücünün artırılmasıydı. Bunun içinde sadece tarım ve madencilik sektörüne dayanılmas1 öngörülmüş ve sonuçta ekonomik temelin görece kuvvetlendirilmesi hedeflenmiştir.

\section{SONUÇ}

İkinci Dünya Savaşı sonrası 1945-1950 yılları arası Türk dış politikasının temeli Sovyetler Birliği, ABD ve Türkiye arasında imzalanan antlaşmalar, görüşmeler ve çıkartılan kanunlara dayanmaktadır.

Mart 1945 'te Sovyetler Birliği, Türk-Sovyet Tarafsızlık ve Saldırmazlık Antlaşmasını feshetti ve ardından Türkiye'nin toprak bütünlüğ̈nü ve bağımsızlı̆̆ını zedeleyecek, kabul edilmesi mümkün olmayan yeni bir antlaşma hazırladı. Bu anlaşma ile Sovyetler, Türk-Sovyet sınırında kendi lehlerine olacak şekilde bir düzenleme yapılmasını, Boğazların ortaklaşa savunulmasını ve üs verilmesini talep ediyordu. Milli Mücadele dönemi boyunca ve sonrasında Sovyetlerle dost kalma çabası içinde olan Türkiye, bu istekler karşısında büyük bir endişe duymaya başladı. Sovyetler Birliği karşısında yalnız kalmamak için İngiltere ve Amerika'nın desteğini kazanmaya çalıştı.

Postdam Konferansında, boğazlar rejiminin değiştirilmesi konusunda bir anlaşmaya varılmadı. Konferansta ABD, Türk boğazlarına milletlerarası bir statü verilmesi fikrini ileri sürmüştü. Ancak daha sonraki süreçte, Boğazların Türkiye'nin egemenliği altında bırakılmasını savunmaya başlamıştır. Bununla da kalmayarak Sovyet yayılmacılığının önünü kesebileceğini düşünerek Türkiye'ye, askeri, ekonomik ve siyasi destekler sağladı. ABD, askeri alanda Truman Doktrini ile ekonomik alanda ise Marshall Planı ile Türkiye'ye destek oldu.

Sonuç olarak Türkiye İkinci Dünya Savaşı'na fiili olarak katılmadığı ve tarafsız kaldığı için savaş sonrasında uluslararası ilişkilerde yalnız kalmıştır. Bu süreçte Sovyetler Birliği'nin doğuda toprak taleplerinde bulunması ve Boğazlardan üs istemesi karşında, Batı Bloğundan destek aramıştır. Bu dönemde daha çok ABD'den destek alan Türkiye, böylece yeni 
dünya düzeni içindeki konumunu da belirlemiş oldu.

\section{KAYNAKÇA}

Alacakaptan, A. G. (1999). Türk-Sovyet ilişkileri. Çağdaş Türk Diplomasisi 200 Ylllık Süreç. Ankara: T.T.K. Yayınları.

Armaoğlu, F. (1931). Belgelerle Türk-Amerikan münasebetleri. Ankara: T.T.K. Yayınları.

Avcıoğlu, D. (1971). Türkiye’nin düzeni (dün-bugün-yarın). Ankara: Bilgi Yayınları.

Barutçu, A. F. (1977). Siyasi anılar. İstanbul: Milliyet Yayınları.

Bilge, S. (1992). Güç komşuluk, Türkiye Sovyetler Birliği ilişkileri 1920-1964. Ankara: T. İş Bankası Kültür Yayınları.

Çelik, E. (1969). 100 soruda Türkiye’nin dış politika tarihi. İstanbul: Gerçek Yayınları.

Erkin, F. C. (1986). Dışişlerinde 34 yll, Ankara: T.T.K. Yayınları

Ertuğ, H. R. (1947). Türk Amerikan mali yardım anlaşması. Siyasi İlimler Mecbuası, 196.

Esmer, A. Ş. (1948). Türkiye'de Marshall planı, Ulus.

Foreign Relations of the United States diplomatic papers, II. (1960). Washington: Department of States Publication.

Gürün, K. (1991). Türk- Sovyet ilişkileri (1920-1953). (1991). Ankara: T.T.K. Yayınları.

Gönlübol, M. (1974). Olaylarla Türk dış politikası, 1919-1973. Ankara: Sevinç Matbaasi.

Marshall planı ve siz. (1950). Ankara: Güney Matbaacılık ve Gazetecilik T.A.O.

Oran, B. (Ed.), (2002). Türk dış politikası: 1919-1980. (6.Basım). İstanbul: İletişim Yayınlar1

Sander, E. (1993). İkinci Dünya Savaşı'nda Türk dış politikası. Olaylarla Türk Dış Politikası 1919-1990, Ankara: Siyasal Kitabevi.

Sarınay, Y. (1988). Türkiye'nin batı ittifakına yönelişi ve Nato'ya girişi. Ankara: Kültür Bakanlığı Yayınları.

Satterthwaite, J.C. (1972). The Truman doctrine: Turkey. Annals of the American Academy of Political and Social Science, 401.

Soysal, İ. (1989). Tarihçeleri ve açıklamaları ile birlikte Türkiye'nin siyasal antlaşmaları, Ankara: C. I-II, T.T.K. Yayınları.

Sönmezoğlu, F. (2006). II. Dünya Savaşı'ndan günümüze Türk dış politikasl, İstanbul: Der Yayınları.

Timur, T. (1991). Türkiye'de çok partili hayata geçiş. İstanbul: İletişim Yayınları.

Tunçkanat, H. (1969). İkili antlaşmaların iç yüzü (ikktisadi, Askeri, Siyasi). Ankara: Ekim Yayınları.

Türkiye dış politikasında 50 yll, İkinci Dünya Savaşı yılları (1939-1946). (1973). Ankara: Dışișleri Bakanlığı Yayınları.

Ülman, H. (1961). Türk- Amerikan diplomatik münasebetleri 1939-1947, Ankara: A.Ü.S.B.F. Yayınları. 
Yetkin, Ç. (2002). Karşı devrim 1945-1950. İstanbul: Otopsi Yayınları.

Resmi Yayınlar

Ayın Tarihi, No: 144, Kasım 1945

Ayın Tarihi, No: 154, Aralık 1945

Ayın Tarihi, No: 154, Eylül 1946

Ayın Tarihi, No: 166, Eylül 1947

Düstur, III. Tertip, Cilt 28, s. 1485-1488

Düstur, III. Tertip, Cilt 29, s. 1278-1289

Arşivler

T.C. Başbakanlık Arşivleri, Cumhuriyet Arşivi, Başbakanlık Basın ve Yayın Umum Müdürlüğü,12.04.1946 tarih ve 101.625.3 nolu belge. 